\title{
CIDADE E NARRATIVAS FILMICAS
}

\author{
Ana Luiza Carvalho da Rocha \\ Cornelia Eckert
}

\section{Tempos cruzados}

\section{Acontecimentos de 1997}

Após 12 anos de um percurso acadêmico identificado com a Antropologia Urbana, obtivemos em 1997 um projeto integrado aprovado no Cnpq e um auxílio financeiro concedido pela Fapergs. Demos início então a uma pesquisa etnográfica tendo por perspectiva o resgate da pluralidade e diversidade de memórias coletivas e da preservação do patrimônio etnológico do mundo urbano, buscando contemplar os lugares da memória dos habitantes de Porto Alegre, sendo esta a cidade de nossas atividades acadêmicas e universo de pesquisa.

O projeto desde então se dedica ao estudo das formas singulares e plurais de construção de tempos sociais vividos na cidade a partir do estudo de memórias e identidades sociais, práticas e saberes de indivíduos e grupos diversos responsáveis pelo agenciamento cotidiano dos dramas da vida urbana. Analisando a cidade a partir dos itinerários urbanos narrados pelos habitantes no seu cotidiano, adotamos novos paradigmas de pesquisa etnográfica objetivando não apenas registrar e documentar os acontecimentos históricos geradores de uma identidade citadina, mas refletir sobre o caráter ético e estético de seus complexos culturais.

A partir de 1998 passamos a cruzar práticas museológicas e etnográficas no estudo do mundo urbano privilegiando a produção de imagens disponibilizadas em um museu virtual. Fomos adequando formas de técnicas de processamento documental, criando condições para uma organização mais dinâmica dos acervos e dos dados de pesquisa, reabilitando o espaço museal como espaço de conhecimento, produção e criação de memórias coletivas.

Com o recurso de novas tecnologias aperfeiçoamos o processo de classificação, catalogação, digitalização e editoração permanente destas imagens no sistema de gerenciamento do suporte criado com a denominação de Banco de Imagens e Efeitos Visuais, dinamizando sua adequação à linguagem WEB, o que permite ao usuário acessar as fontes que estão na origem da base de dados etnográficas do Projeto Integrado. Estes encaminhamentos permitiram o incremento de um processo de informatização dos dados de pesquisa, com vistas a disponibilizá-los aos demais 
pesquisadores interessados no tema da memória coletiva na cidade e tendo por intenção reunir coleções de documentos etnográficos, nos seus suportes mais diferenciados (imagem em vídeo, filme, som e grafia).

Em especial, o Banco de Imagens e Efeitos Visuais, concebido a partir deste Projeto, trabalhando com conjuntos documentais diversos sobre a cidade de Porto Alegre, oportunizou uma investigação mais detalhada dos sistemas de representações (imagens e valores) que caracterizam a vida na cidade tanto dos locais de pertencimento em seus territórios urbanos, quanto de suas redes afetivas, instrumentos significativos para a construção de rede de organização da base de dados do Projeto e do resgate de suas informações pelo usuário. Disponibiliza-se estas imagens em programas de formas interativas de documentação, registro, apropriação e produção de memória coletiva integrando novas tecnologias.

\section{Acontecimentos de 2001}

Em 1999, o Prof. Dr. Jean Arlaud, antropólogo francês coordenador do Laboratório de Antropologia visual e sonora do mundo contemporâneo da Universidade de Paris VII em Paris, respondeu de forma positiva à nossa produção científica encaminhada àquele centro e propôs um intercâmbio científico com o Banco de Imagens e Efeitos Visuais.

Este retorno nos mobilizou a um estágio de pós-doutoramento na França buscando avançar em nossa reflexão sobre a produção em imagens de pesquisas etnográficas que portam profunda reflexão conceitual. O que para nós consistia em ampliar uma discussão epistemológica, ou seja, como traduzir em imagens fatos etnográficos construídos em processos de pesquisa antropológica. Buscamos refletir sobre esta interface entre antropologia e a produção audio-visual, analisando documentários em sua intertextualidade, recorrendo a interpretações diferenciadas seja na sua especificidade histórica, seja na sua singularidade técnica.

Inter-relacionando métodos de pesquisa da antropologia urbana e visual e integrando novas tecnologias, permanecemos no laboratório francês até março de 2002, dando encaminhamento as nossas aspirações de conhecer o tratamento da imagem dada por cientistas e intelectuais franceses às pesquisas "da" e "na" cidade, reconhecendo as estratégias teórico-metodológicas adotadas em 
áudio-visual para produzir estudos sobre o fenômeno urbano e sobre as feições contemporâneas do viver, agir e pensar dos habitantes nas cidades.

\section{Interpretando documentários}

Em Paris, a oportunidade de desenvolver uma pesquisa de 2001 a 2002, consistiu entre outras atividades o inventário das produções de documentários áudio-visuais franceses que tinham a cidade como foco narrativo.

Um primeiro passo foi situar a filiação da narrativa fílmica às formas representacionais de domesticação do tempo que fundam a cidade moderna, urbano-industrial de fins do séc. XIX, uma retórica que se funda na exploração da acuidade dos traços tanto sensoriais quanto visuais da imagem-movimento. Segundo Jean Bazin (2000:65) encontramos os desvendamentos deste legado nos processos "expressionistas" da montagem inclusa nos filmes mudos e que se traduz no estreito diálogo entre a mística da imagem fílmica e o processo de exacerbação dos sentidos tanto quanto se manifestam nos espetáculos ilusionistas, conforme aponta Arlindo Machado (1997), em sua arqueologia das formas fílmicas. Seguindo a pista dos comentários destes dois autores, o que nos despertava atenção era compreender a linguagem cinematográfica como partícipe do ambiente psicossocial das sociedades urbano-industriais, expressão da consciência poética das inquietudes do homem moderno face à fuga do Tempo.

Se nos seus primórdios a narrativa fílmica nasce vinculada a arte do espetáculo e do divertimento popular, posteriormente, ela se transforma desde produto de propaganda ideológica até objeto de expressão artística. De um jeito ou outro, a narrativa cinematográfica se nutre da imaginação humana (Durand, 1979), indo além de seu papel de "janela" para o mundo, para se afirmar, progressivamente, no corpo das motivações simbólicas da ordem "humanista e positivista da história", como "espelho" do mundo. Segundo André Bazin (2000:65), estas motivações mostravam que "les véritables primitifs du cinéma [...] sont à l'imitation intégrale de la nature" (Bazin, 2000:23).

Neste ponto, mesmo o gênero documental, em seu "recital de imagens" esteve, em graus diversos, comprometidos com o caráter ilusionista e as funções mágicas ligadas às origens da narrativa fílmica. $\mathrm{O}$ aspecto ilusionista da imagem filmica, ainda que encoberto no processo de 
evolução da linguagem cinematográfica, nos permite afirmar, com Jean Bazin, que, seja pelo conteúdo plástico da imagem, seja pelo recurso da montagem, "a narrativa filmica permite ao citadino se confrontar ou aderir aos efeitos de duração de suas imagens e recria nele as imagens mentais de seus deslocamentos nos grandes centros urbanos" (Bazin, 2000:65) (T.A).

Uma afirmação que nos permite fazer um paralelismo: assim como viver a cidade moderna traz um desafio para os seus habitantes, qual seja, construir um sentido para suas experiência num mundo de fragmentações dos papéis sociais e de descontinuidades de códigos éticos, o cinema exige do espectador que ele se conforme a uma narrativa em que o espaço de enunciação (salas de exibição) se caracteriza essencialmente pela negação de seu suporte técnico, fragmentado e granulado. Neste sentido, as maneiras de habitar a cidade moderna contribuem ao nascimento da figura do espectador tornando seus habitantes aptos a aderir à imagem cinematográfica no movimento circular das narrativas da vida urbana.

\section{Actualités Gaumont: o mundo nas mãos da aeromoça}

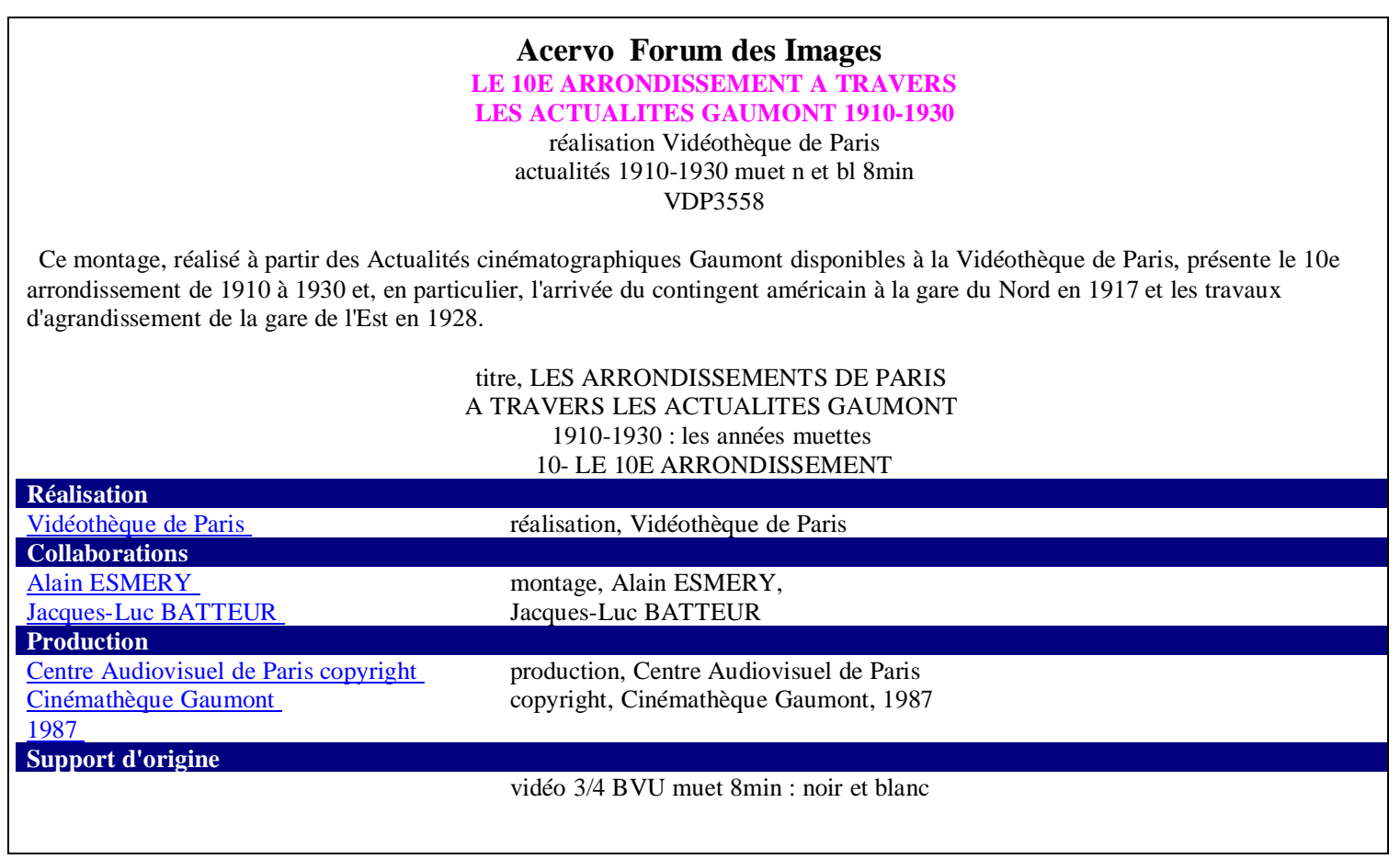


Sentadas em confortáveis poltronas que nos permitiam imaginar a sensação de viajar em algum Boeing 747, tendo um maquinário computadorizado a nossa disposição com teclados eletrônicos instalados em cabines equipadas, podíamos diariamente assistir toda e qualquer imagem fílmica que se relacionasse à cidade de Paris. O templo freqüentado denomina-se "Fórum des Images", localizado no centro comercial Les Halles, na área central de Paris.

Iniciamos nossa pesquisa consultando os noticiários que fizeram época no século XX.

A imagem de um avião pousado de onde saía uma aeromoça com o símbolo da Gaumont, nos permitia um mergulho em lembranças da nossa infância ao revermos as séries jornalísticas intituladas Actualités, reportagens especialmente feitas para circular no mercado do cinema. Tratase de um noticiário que destaca os eventos importantes da nação às esquisitices de um mundo de novidades e inventores criativos. A cidade era a decoração central, em especial Paris, como testemunham os trechos assistidos sobre a conjuntura do pós-guerra, com cenas da liberação da cidade tanto quanto as clássicas imagens da manifestação de maio de 1968.

As imagens atualizam aos espectadores sobre o incêndio do Moulin Rouge (fevereiro de 1915), sobre a consagração da Basílica do Sacré-Coeur (1919), sobre a chegada dos contingentes americanos na Gare du Nord (1917) das reformas na Gare de l'Est (1928) dos festejos populares e outros eventos comemorativos na cidade de Paris.

Nestas narrativas filmicas, as grandes cidades constituíram paisagens de escolhas e projetos, na medida em elas traduzem, no plano estético da imagem-movimento, um lugar de circulação intensa onde os homens, as coisas e as idéias - mas também as técnicas e os investimentos capitais - cruzam as fronteiras nacionais.

A diversidade e o cosmopolitismo das cidades, à época essencialmente em transformação, refletem os traços singulares que o cinema conferiu, seja em documentários, mas também na ficção, um sentido especial. O esforço era divulgar uma imagem progressista para um público cultivado e testemunharia seu tempo, e as conquistas dos Estados-nações. Neste sentido, transformavam a vida citadina em uma novela jornalística a ser consumida diariamente, onde intrigas eram captadas e estilos de vida de uma burguesia ascendente, idealizadas. Como não

\footnotetext{
${ }^{1}$ http://www.forumdesimages.net// Conforme anuncia este WebSite : A memória audiovisual de Paris e de sua periferia : 6500 filmes de 1895 aos nossos dias, ficções, documentários, atualidades, publicidades, emissões de televisão, filmes amadores, longas e curtas metragens. Consulta, 18 agosto 2003.
} 
lembrar aqui a fundação do mito de Paris que conhecemos como a "Belle Époque", e cujas imagens foram perpetuadas em filmes hollywoodianos que traziam a cidade como cenário.

Reconhecido abertamente o processo de caricatura de uma realidade, as actualités, embora tivessem a pretensão de registro do vivido humano e dos fatos reais, ao final, foram responsáveis por um dos primeiros movimentos da perda do olhar ingênuo sobre a imagem fílmica. Processo em que devemos considerar o nascimento de uma filosofia da suspeita (Mikhail Bakhtin) que se aplica desde então à narrativa em imagens e que vai dar origem à criação de novos gêneros de escritura cinematográfica, como ocorreu com o chamado filme documentário que emerge de novos contextos políticos e sociais.

\section{A civilização e a imagem do Outro: Tarzan nas selvas e o distante selvagem}

Dos cinematógrafos dos anos 1890 às salas de projeção atuais, o cinema, como a cidade, sofreu as alterações significativas. A evolução do ato de filmar a cidade acompanhou desta forma o contexto de crise do mundo contemporâneo e as formas da vida social próprias aos grandes centros industriais. Em sua preocupação de alargar seu testemunho para além da "civilização urbana" e da exploração de seu lado espetacular, a imagem cinematográfica das "atualidades" se dedicará ao registro de documentários que evocavam as culturas e povos tradicionais ameaçados de extinção face o avanço da civilização. Entretanto, a intenção de dar uma imagem autêntica do Outro não receberá o mesmo tratamento de "ilusão de verdade" que as formas da vida urbana moderna. Neste mesmo registro, mas de modo distinto, os filmes de expedição e exploração, à moda nos anos 1920 e 1930, serão sempre vistos como exemplos de falsificação das representações colonialistas do Outro aos olhos daquele que detém a câmera.

«Depois da guerra, assistimos a um retorno evidente da autenticidade documental [...] o ciclo do exotismo foi interrompido, o público exige acreditar naquilo que ele vê e sua confiança é controlada por outros meios de informação que ele dispõe, o rádio, o livro, a imprensa. O renascimento do cinema de longa duração renasce da exploração cuja mística pode bem se constitutir numa variante do exostimo de pós-guerra. Se o sensacional não foi banido por princípio, ele foi subordinado à intenção objetivante do documentário de emprendimento sendo raro que a câmera seja testemunha dos momentos mais perigosos de uma expedição. Em revanche, o elemento psicológico e humano passa ao primeiro plano. Os comportamentos e reações diante da missão a se realizar , uma espécie de etnografia de explorador, uma psicologia experimental da aventura, seja em relação aos povos contatados e estudados. Paramos de tratá-los como uma variedade de animais domésticos, esforçando-nos para melhor descrevê-los e compreendê-los. Vê-se claramente se formar uma mitologia com o espírito ocidental investindo na compreensão de uma civilização distante. A mística moderna do exotismo remodelado por novos meios de comunicação, refere-se a um exotismo instantâneo, cuja expressão mais típica é o filme de montagem do início do filme falado onde toda a terra é projetada na tela como um puzzle de imagens visuais e sonoras».

Ficha de Leitura (Bazin, 2000) 
Segundo o Dicionário do Cinema organizado por Jean-Loup (Paris, Larousse, 1995), foi em 1926 que o termo "documentário" foi empregado pela primeira vez para classificar uma obra cinematográfica. Na ocasião John Grierson publicara no jornal The Sun este conceito para referir-se ao filme de Robert Flaherty, Moana (de 1926) e tentava qualificar uma obra cinematográfica que não se baseava na ficção e que tinha por objetivo descrever ou restituir o real, diferenciando do "tratamento criativo da atualidade" (Passek, 1995). Na condição de documentário, é que várias obras fílmicas passam a compor um patrimônio das sociedades e culturas humanas, entre os quais é sempre impossível deixar de citar o excepcional filme de Robert Flaherty, Nanook of the north, sobretudo pelo impacto que a linguagem visual das ações em sequiência com a inclusão de champs et contre-champs, movimentos panorâmicos e ângulos de prise de vue, delineou no campo cinematográfico documental.

\section{O documentário e o vivido}

O segundo filme, e talvez o mais citado de todos os tempos no rang dos documentários referidos pelo ao ato de filmar a cidade descobrindo nela sua carga de exotismo, é o de Dziga Vertov, L'homme à la caméra, ou uma «prosa à vida», refere-se ao conhecido movimento do cinéma-oeil (1924), com recurso à câmera escondida na mimese ao olho humano destituído do corpo, na captação e impressões.
Os dois aportes fundamentais da prática de Vertov, a noção de montagem interrompida e a noção de intervalo: «todo o filme do cine-olho é uma montagem desde o momento onde se escolhe o tema até o momento da exibição da película definitiva, ou seja, um filme está em montagem durante todo o seu processo de fabricação.» [...] a montagem, então, precede, acompanha, transforma e excede a representação. A base desta prática da montagem se encontra na noção de intervalo como fundo contraditório irredutível. O movimento é pensado já como contradição por Vertov: «a matéria primeira da arte do movimento, não é o movimento em si, mas os intervalos, a passagem de um movimento a outro. São os intervalos que engendram a ação na direção de uma solução cinética» [...] «a progressão entre as imagens - intervalos e correlações visuais das imagens é - (para o cine-olho) uma unidade complexa. Ela é formada da soma das diferentes correlações (planos, ângulos, movimentos de imagens, luz, sombras, velocidade de gravação.)

Ficha de leitura (Gervaiseau\&Vertov, 1996)

A imagem ascendia a um novo estatuto de documento, aderindo as evidências do mundo dos objetos e do mundo das idéias que este abrangia. 
Com a obra de Dziga Vertov entre outros cineastas, ficava evidente que não são apenas os sociólogos que se dedicavam a atender o fenômeno urbano na cidade-laboratório de Chicago (USA). A narrativa filmica das três primeiras décadas do séc. XX, de forma mais expressiva, irá se ocupar das selvas urbanas, registrando as preocupações narcíseas de toda uma época, tal como aparece nas obras de André Sauvage de 1928, Etudes sur Paris, de Jean Vigo a conhecidíssima $A$ propôs de Nice ou de Walter Ruttmann Berlin, Symphonie d'une grande ville de 1927. Posteriormente, nos anos 1940, as obras de Georges Rouquier, Farrebique, e de Robert Flaherty Louisiana Story irão registrar uma dupla tradição do gênero documental ao retratarem os fatos da vida social pela valorização da arte de montagem e edição. Diferente dos tempos que se seguirão, estes gêneros do documental, se apóiam sobre a progressista indústria de entretenimento onde os temas relacionados à exploração dos povos, à ameaça de extinção de culturas, a crise do mundo rural e ao crescimento vertiginosos das grandes metrópoles, eram retratados ainda sob um ponto de vista romântico.

Certamente foram as duas grandes catástrofes das guerras mundiais que despertaram o caráter testemunhal da narrativa cinematográfica, conjuntura em que o gênero documental irá adotar como razão de produção a fonte de informação e propaganda governamentais. Nestes eventos bélicos, em que cidades inteiras são destruídas, a narrativa filmica se vale do acúmulo de imagens de arquivos, que se tornam acessíveis aos espectadores na forma de uma história oficial. Trata-se de imagens susceptíveis de participar da construção de uma memória social que se mostrava ainda capaz de servir simultaneamente a inúmeras banalizações.

Novos contextos políticos propõem novos dilemas e dilacerações. Neste ínterim os documentários franceses como Le silence de Paris, de J.-C. Bringuier (1957), L'effondrement, de M. Ophuls (1967), Une journée portée disparue, de P. Brooks et A. Hayling (1992) ou Le fond de l'air est rouge, de Chris Marker (1997), tecem diálogos e interpretações que nos incluem na circularidade das idéias e imagens dos testemunhos da história contemporânea da França profunda. Suas imagens evocam o homem da rua como co-autor de questões e respostas na trajetória de alienações, resistências, pactos e rupturas de gerações na cultura francesa. O filme documentário dos anos pós-guerra, re-habilita a imagem filmica como um instrumento possível, uma maneira acessível de contar sobre o mundo guardando por temática central a duração da memória coletiva. 
Por tudo isto, cabe pensar se, na contemporaneidade a imagem documental responde, nesta perspectiva, às angústias temporais do homem moderno, permitindo ao habitante das grandes cidades, pela via de sua relação à memória, desconfiar e duvidar do passado tal como descrito por imagens e discursos oficiais.

A câmera abusa da posição plogée, exagera nos planos gerais dos carrefours de avenidas e boulevards em perspectiva onde os prédios contrastam com as pessoas e os movimentos dos carros. Imagens cujo enquadramento faz alusão a Paris dos filmes americanos dos anos 50. No primeiro tempo, a câmera privilegia as imagens monumentais e turísticas da cidade. Tomadas da Tour Eifell, Arco do Triunfo, Place de la Concorde, etc. Das grandes panorâmicas a câmera se desloca para as calçadas. O documentarista segue um percurso «etnográfico»a respeito do enquadramento de um ponto de vista sobre a cidade parisiense, o roteiro é o grande responsável por reunir os fragmentos de imagens e sons captados. Ele explora o antagonismo entre grupos e indivíduos nas ruas; antagonismo de personagens e de ambiências urbanas apresentadas dentro de um mosaico de diferenças sociais, étnicas, econômicas e suas relações com a cidade de Paris. Imagens de operários nas ruas e nas saídas das usinas automobilísticas, nas periferias, nas suas vielas pobres. Os imigrantes argelinos em seus acampamentos miseráveis, mulheres e crianças mendigando em Paris, véspera da guerra da Argélia. Histórias de guerra, de morte e tortura.

Ficha Filmográfica de 23 julho 2001

Le Joli Mai, 1962

Nas ruas de Paris, o documentarista coloca questões aos pedestres e vendedores, o diálogo se desenrola diante da câmera que não é prisioneira deste encontro efêmero, ela investiga o ambiente, se desloca ao redor da interação humana. Ela busca o melhor ângulo, a melhor tomada, o melhor ponto de vista do encontro. A câmera registra os gestos, os movimentos, explorando a troca entre entrevistado e entrevistador. O momento é subversivo e inventivo, a câmera encontra sua inspiração no cinema direto. A montagem aproveita o ritmo da câmera ágil, no contraponto com a câmera fixa, contemplativa, à espera da reação do passante. A câmera intimida, os personagens tem um ar confessional, os diálogos se sucedem numa ambiência intimista, às vezes, numa atmosfera de indiferença como do flânneur de Baudelaire ou Benjamin. Quase uma interpretação especialmente construída para o olhar indiscreto da câmera.

A cidade de Paris nos anos 1960 e os temas do desemprego, dos preconceitos de classe, do racismo, da guerra da Argélia. São as heranças dos anos pos II GG : a solidão, a indiferença, a busca de si-mesmo de riqueza e de dinheiro, de trabalho, enfim, da felicidade. A procura de felicidade, «sou feliz ou não sou?» está presente nos novos tempos. Tempo que desvenda o início da contra-cultura, da negação da sociedade de consumo, da alienação pelo trabalho.

A busca de outros estilos de vida e outras formas de estar-junto na Paris do início dos anos 60, anunciam-se as origens dos protestos sociais que ocorrerão m maio de 1968. Uma camera que acompanha os personagens mas não traduz seu ponto de vista. Não se trata de uma câmera subjetiva. Ela se desloca com os personagens, os observa dormirem, acordando, ou quando andam pela cidade, conversam com os amigos, etc.

Ela observa, toma nota, registra a vida cotidiana dos personagens mas sempre sob o ponto de vista do etnógrafo que está alí e participa da cena. É uma camera que ao mesmo tempo quer registrar os pensamentos íntimos dos personagens tanto quanto interrogá-los sobre seus sonhos e desilusões, indiscreta ou não, feliz ou infeliz para cada um deles.

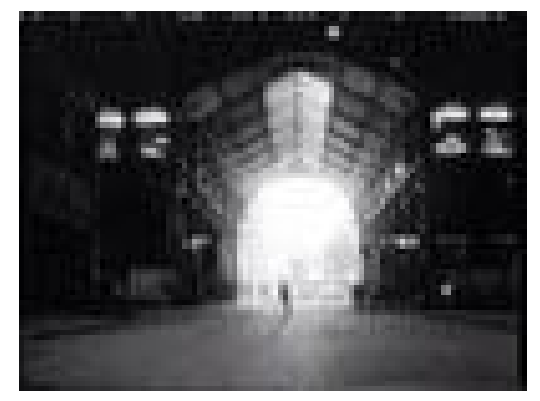

Ficha Filmográfica 13 junho 2001

Chronique d'un été, 1960. 
O documentário francês dos anos 1960 e 70 é um exemplo da forma como a imagem documental pretende restaurar a sociedade moderna. Imagens do enfretamento do próprio documentarista com o fenômeno que ele registra, ela própria contém a aspereza das crises sociais que ela retrata. Tão áspera e crua que chegamos a pensar que trata-se de cinema ficcional. Com ela habitamos os casebres dos imigrantes na luta contra suas míseras condições de vida, as ilusões de consumo das camadas médias, as culpas das elites locais face ao avanço da pobreza.

Os temas retratados giram em torno do dinheiro, do amor, da guerra, do racismo, do trabalho das mulheres, dos problemas da habitação, do desemprego e da crise política. Geralmente os personages são pessoas anônimas, comuns e ordinárias; os cenários são as ruas, as casas de comércio, os locais de trabalho, das praças (predominando espaços públicos) de uma Paris cada vez mais cosmopolita, perigosamente pluriétnica e pluriracial.

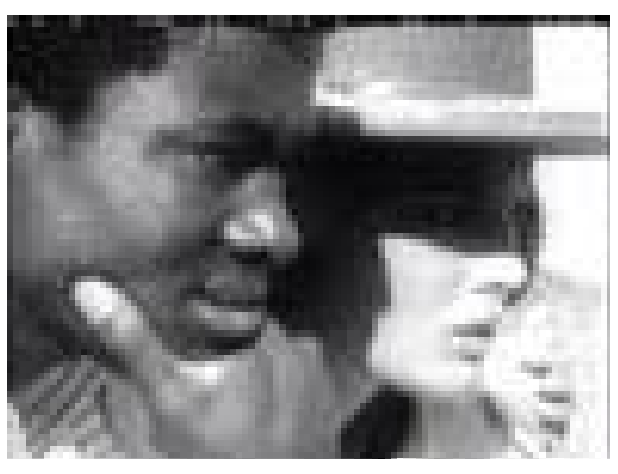

Landry e Jeane, Chronique d'un été, 1960.

Cada vez mais, longe da Paris glamourosa dos filmes dos anos 1940 e 50, nos confrontamos com os velhos bairros, edifícios decadentes sem água e sem aquecimento, becos sujos repletos de animais domésticos e lixo, corredores escuros por onde transitam crianças e mulheres por meio a roupas dependuras, expostas. É lá que a câmera do cinema direto vai procurar seus personagens. Uma vida coletiva que subverte a cultura oficial francesa, através de estilos de vida transplantados para uma capital européia, sistemas de práticas e saberes estranhos ao parisiense que reúne os «extrangeiros » oriundos das antigas colônias de um império francês em crise: África, Indonésia, Antilhas.

A Paris, cultuada cidade-luz torna-se, em fins dos anos 1960, um microcosmo das formas de vida das sociedades complexas, contemporâneas, urbanas e industriais onde o exotismo se apropria da figura do cidadão. Um número expressivo de documentaristas está atento a estas transformações e paradoxos da cidade francesa. As reformas urbanas são tema recorrentes, tratando sobretudo dos processos de expulsão e expropriação de habitações vetustas em bairros centrais de Paris. A violência dos acontecimentos e experiências de humilhação captada pelos cineastas contrastam com as propagandas governamentais sobre os novos bairros HLM de moradias populares, incitando a franceses e estrangeiros se fixarem nas periferias da capital, em 
apartamentos standard, em edifícios homogeneizados pela ótica de uma arquitetura moderna, higienizada e popular. Neste propósito inventariamos os documentários de Robert Bozzi intitulado Les gens de baraques (1995), o filme Rue des Partants de Gilles Dinnematin (1995), Babelville de Philippe Baron (1992), entre outros.

Neste processo, o cinema direto ou por que não dizer "etnográfico" "da" e "na" cidade contribui sobre o debate do que denominamos documentário do contexto urbano francês. De fato a chamada antropologia visual continua a se interrogar sobre a autenticidade etnográfica da imagem cinematográfica considerando-a como diz André Leroi-Gourhan, como uma imagem insubstituível das pessoas em suas épocas e nos seus meios (Héritier, 1992:13).

\section{Crônicas da e na cidade}

Jean Rouch, este importante cineasta antropólogo, apesar da idade estava sempre pontualmente presente nas aulas de sábados pela manhã no Séminaire Cinéma et Sciences Humaines na Cinémathèque Française, ao longo de 2001, surpreendendo a todos com suas reminiscências de uma trajetória desde já referida como legendária.

Em discursos inflados sobre a continuidade da existência do Museu do Homem, alvo de políticas de desmobilização, Jean Rouch relacionava sua obra na África, as culturas nas colônias ao conhecimento que o homem ocidental deve resguardar no coração da sua amada Paris.

Jean Rouch, Chronique d'un été "ante-sala" do filme

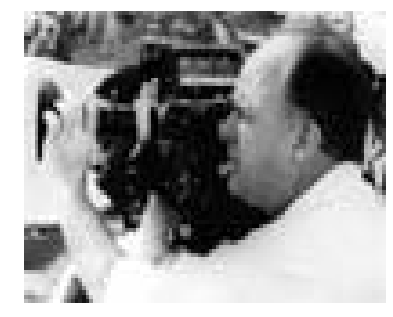

"Moi un noir de Jean Rouch, disse Godard, foi uma pedrada no charco do cinema francês como a "cidade aberta" em Roma, impactou na sua época o cinema mundial. E disse ainda que muito do seu próprio cinema, Godard deve a este filme. Diz ainda que muito do seu próprio cinema se deve a este filme. A fita desenrola-se em Treichville, bairro de lata de Abdijan, na Costa do Marfim, com cinco atores não profissionais: um desempenhando o papel de Edward Robinson, outro de Eddie Constantine, outro o de Tarzan e uma atriz representando Dorothy Lamour, todos estrelas do cinema americano. $\mathrm{O}$ filme é rodado sem som e sonorizado na pós-produção com uma voz over, os comentários espontâneos de Oumarou Ganda, que desempenhava o papel de Edward Robinson. Oumarou tinha feito a guerra da IndoChina e sempre sentira não ter nascido para o trabalho. O seu maior sonho era tornar-se ator de cinema. Realizado o sonho, só não entende por que carga de água ganhava no mesmo ofício Eddie Constantine 800 milhões de francos enquanto ele ficava a ver estrelas. Esta obsessão de Rouch em fazer de gente anônima estrelas de cinema não deixa de ter outras e mais graves consequiências. [....] Onde é que isto vai dar? Nas seqüências puras: a câmara vai ao sabor do olhar, num devaneio pelo real, detendo-se no mais evidente, deixando-se prender. Para ser fiel ao propósito de registrar a verdade da forma mais pura, em plano seqüência, a câmara segue os acontecimentos sem interrupção e sem mudança de ponto de vista. Interromper o plano e mudar de ponto de vista significa um corte: um hiato na continuidade, a omissão de um lapso de tempo da ação, uma pausa do olhar, ou então uma mudança de perspectiva que não respeita a situação no espaço do corpo do observador, que altera o ritmo do real e vai introduzir no filme mais um artifício (já não basta o da câmara!): a montagem".

Ficha de Leitura

A outra face do espelho. Jean Rouch e o "outro"

Ricardo Costa 
A escola de Jean Rouch, a da antropologia compartilhada, não nasceu apenas na África, mas igualmente nos documentários desenvolvidos na cidade, sobre formas de interação e reconhecimento da vida cotidiana, nos dramas dos personagens em sequiência real como no filme Moi, un noir. Em questão, as representações da realidade que nós atribuímos às imagens do Outro.

O documentário Chronique d'un éte que Rouch realiza com Edgar Morin, em 1960, é um ponto alto desta reflexão. Filme realizado com a colaboração técnica de Michel Brault do Office du Film Canadien, a idéia era testemunhar o vivido enquanto sintoma de um vazio de significações. O filme relança cada um dos seus atores, "gente comum", numa nova carreira, só por ter feito deles, durante uns tempos, estrelas de cinema.

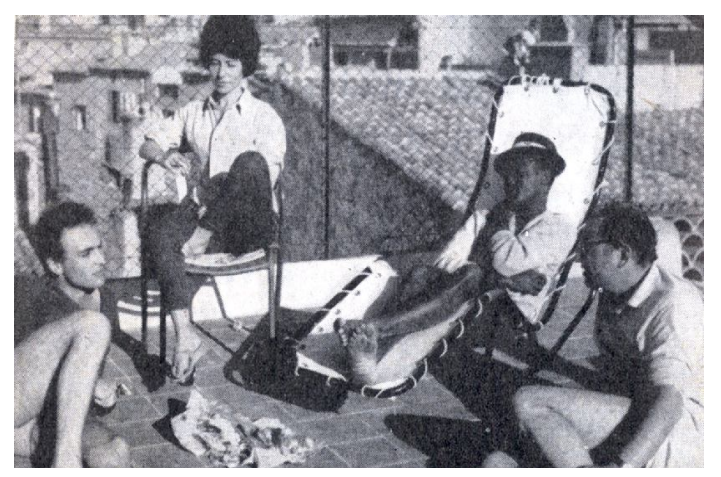

Edgar Morin, o sociólogo que escrevera um livro já célebre, Le cinéma ou l'homme imaginaire, que ele sub-intitula de 'ensaio de antropologia', autor de um outro texto sobre as estrelas de cinema, Les Stars, antigo membro da resistência, expulso do partido comunista por ser anti-estalinista, editor da revista Arguments, admirador do trabalho de Rouch, propõe-lhe fazer um filme com a intervenção de alguns dos seus amigos: um quadro social sobre Paris de 1960. Rouch responde: 'Je ne suis pas un fresqueur'. Mas aceita. Morin tem um argumento de peso: diz que, ao extinguir-se, o século XIX legou ao homem duas máquinas novas, que acabariam por vencer a barreira do som.

Questão mecânica: para conseguir o efeito havia que aperfeiçoar a máquina. Começou Rouch o filme, Chronique d'un été (1960), com uma Arriflex, já bastante leve (pesava uns dez quilos), mas, a seu ver, demasiado pesada para ultrapassar a estratosfera. Não era bem o gênero de máquina que lhe convinha. Para obter o que pretendia, Jean Rouch atacava em duas frentes: a construção de um aparelho mais leve e a adaptação de um motor auxiliar que lhe permitisse ultrapassar "a barreira do som".

Questão filosófica:

Morin reconhece que Rouch, ultrapassando as fronteiras pisadas por Flaherty e por Vertov, os pioneiros, os ultrapassa nos seus propósitos de "penetrar para lá das aparências, das defesas,

entrar no universo

desconhecido do

quotidiano".

\section{Ficha de Leitura}

A outra face do

espelho.

Jean Rouch e o

"outro"

\section{Ricardo Costa}

Rouch e Morin,

Museu do Homem

Paris

Chroniques d'un été,

1960

Jean-Pierre, Marceline, Landry e Morin

Chroniques d'un été, 1960. 


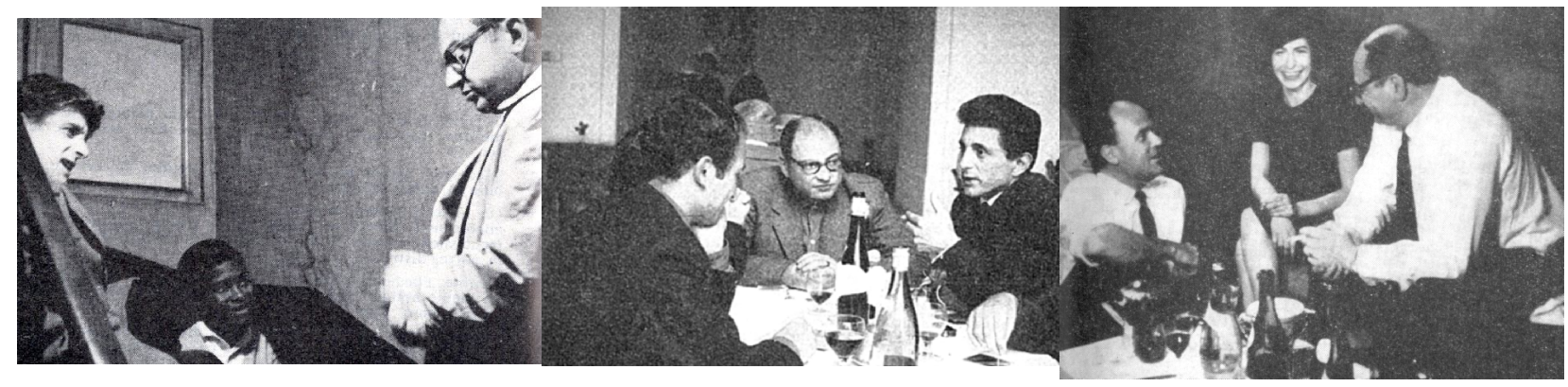

Ângelo, Landry e Morin

Reunião, estudantes e operários

Morin, Marceline e Rouch Morin, Jean-Pierre, Regis,

Ângelo e Jean.

Chroniques d'un été, 1960.

Ricardo Costa (2000) nos provoca aqui com uma questão pertinente. Chronique d'un éte é um documentário ou trata-se de uma pesquisa? E como negar sua força epistemológica ao vermos nesta produção uma experiência de interrogação do próprio campo cinematográfico? Jean Rouch lança novas questões na escola do cinema, dialogando com o conhecimento que o antecede, o "cine-olho" de Vertov, a "câmara participante" de Flaherty e propõe olhar as sociedades que lhe são estranhas e as que lhe são familiares a partir do cinema direto, da câmera subjetiva no contexto objetivo da intenção científica: "O plano seqüência é o mais fiel amigo, faz ver sem cortes, narra sem montagem. Jean Rouch adota-o como ética, o lado não visível de uma realidade, algo que, escapando à observação, só pela imaginação pode ser discernido" (Costa, 2000).

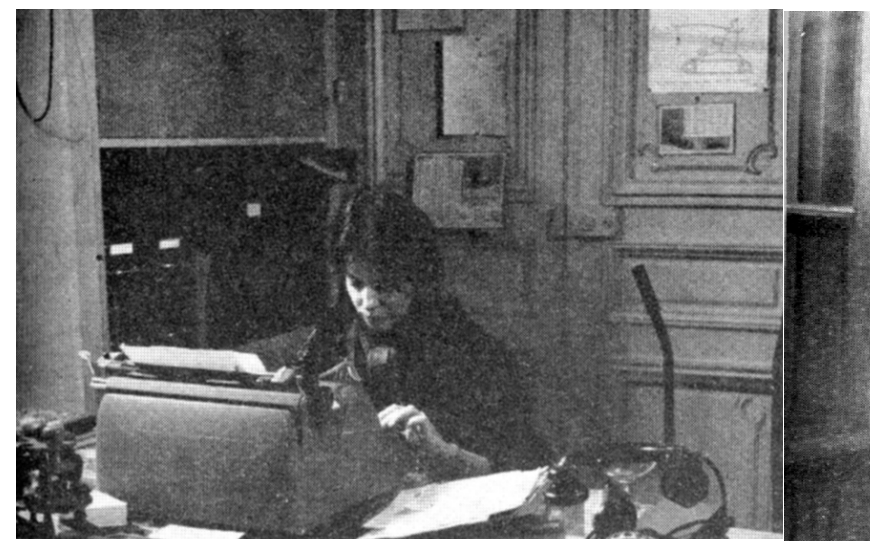

Marilou no trabalho

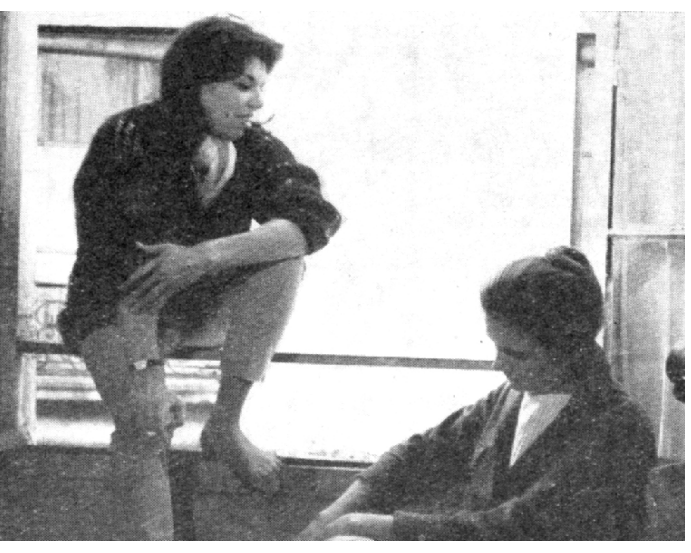

Marilou e Jeane(não incluído no filme)

Chroniques d'un été, 1960 
É esse o objetivo das imagens do cineverdade em sua busca de etnografia da cidade: atingir com vinte e cinco horas de rushes. Surgem exigências dos produtores e divergem os dois autores na montagem. Jean Rouch argumenta: "A minha posição é a seguinte, o interesse de toda esta história é o filme, é a cronologia da evolução das pessoas em função do filme". Neste sentido, o plano-sequiência, o único que corresponde a um observador que se move no espaço e que, sem pestanejar, segue qualquer coisa: um personagem ou uma idéia.

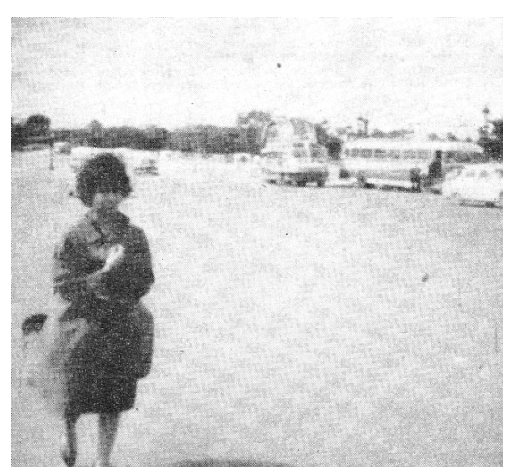

Marceline, Place de la Concorde, Paris.
Um exemplo do cinema verdade, independente do que ela seja. A ambiência dos anos 60, na França e em Paris. Um grupo de intelectuais, uma pesquisa sobre a felicidade (as pessoas são felizes ou não?) e a intenção de registrar os fatos sociológicos a propósito das condições de vida diversas camadas sociais (o motivo). Os personagens: homens, mulheres e crianças (gerações); a família e os singles, as camadas médias e as camadas populares, só intelectuais e os trabalhadores, o colonizador e o colonizado, os negros e os brancos, etc. Cena do diálogo entre Morin e Rouch à propósito do desemprego e da pressão sobre um personagem ser despedido do seu trabalho na usina; o operário "em férias" na praia de Saint -Tropez com os amigos e a família de Morin; o diálogo de uma família de camadas médias num HLM em torno da janta, sobre dinheiro e consumo; os intelectuais brancos e o africano no café do Museu do Homem; a entrevista do operário e do adolescente africano sobe a França; o trabalho e os excluídos. Cine-verdade: cenas do cotidiano de personagens que se misturam aos diálogos de Rouch e Morin sobre o prosseguimento do documentário, discutese como prosseguir a história. Um ponto de vista bretchiniano para interromper a narrativa "realista" da história, os comentários são feitos para que se saiba que a história está sendo construída sob os nossos olhos. A obsessão pelo testemunho é tão grande que o filme se pretende desnudar o próprio roteiro. É necessário dar a impressão de verdadeiro, de verdadeiro, a verdade da verdade... é o real como construção. Isto coloca alguns problemas: haverá verdade nos personagens desta estória ou não, uma vez que eles se deixem filmar [...] em cada instante de suas vidas a câmera lá esta. É o real como construção.

Ficha Filmográfica 15 junho 2001

Chroniques d'un été, 1960

Chronique d'un été. 1960 
A imagem cinematográfica não estará mais no centro das interpretações, como na época inicial dos documentários, mas antes a crítica social, será igualmente um olhar sobre subjetividades e conflitos de interpretação.

Os olhares de documentaristas herdeiros do cinema verdade e compartilhado seguem a escola de Jean Rouch. Louis Malle filma em seqüência o cotidiano na praça da República (Place de la Republique, 1969) em Paris ou traz a condição do viver em Calcutta como drama social. Agnès Varda produz Daguerréotype (1975), e Raymond Depardon Délits flagrants (1994), entre outros.

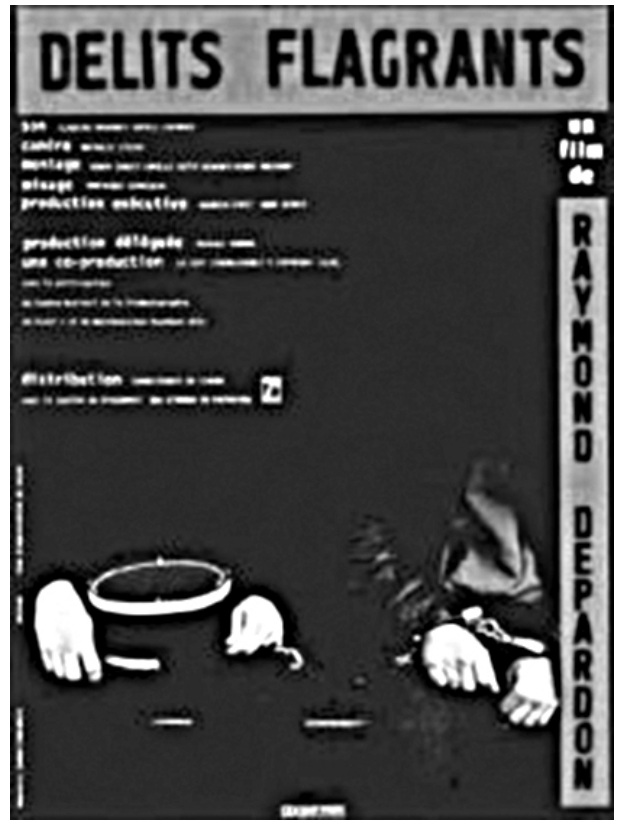

"Eu não gosto da palavra documentário, pois, no momento em que se diz documentário, as pessoas pensam que isto vai ser a jato. Mas há filmes que eu admiro muito na minha vida, como os de R. Flaherty, Louisiana Story, l'homme d'Aran, e que são muito elaborados, cujas condições de filmagem assemelha-se a um cinema de ficção. Eu não poderia fazer estes documentários por eles mesmos, o que eu adoro fazer como documentários é precisamente o que se chama hoje de cinema direto, caso do documentário Place de la Republique. Em "Place de la Republique" nós filmamos tudo em 8 dias; explorando cem metros de calçadas. Evidentemente, eu não escolhi esta quadra por acaso; trata-se de um território muito popular, extremamente sincrético em termos das etnias que lá habitam. A praça é um lugar de passagem e de permanência, ao mesmo tempo de butiques e de vendedores ambulantes. Nós chegamos a calçada com meus dois companheiros de aventura: Etienne Becker na câmera e Jean-Claude Laureux operando o som .e durante uma semana abordamos as pessoas que passavam pelo local. A idéia era conhecer essas pessoas que por ali passavam e, depois, com a sua concordância, nós os filmávamos. Geralmente os passantes respondiam que não tinham tempo, que estavam apressados. Ao final desta semana, eu me encontrava diante de um material. Sem dúvida, havia uma encenação das pessoas diante da câmera, na medida em que havia uma série de escolhas de enquadramento e captação de imagens, mas nós fazíamos estas escolhas diante do momento vivido com as pessoas na rua. Somente depois, na montagem, nos perguntávamos como encadear estas imagens.

Isto ocorre também no cinema ficcional, mas no caso do documentario é mais grave, pois temos o tempo para refletir e escolher a cena a ser filmada. É absurdo afirmar que o cinema direto é objetivo. Estamos interpretando todo o tempo, pelo olhar e a posição da câmera, na escolha do que filmamos ou não".

Ficha de Leitura

Louis Malle par lui-même

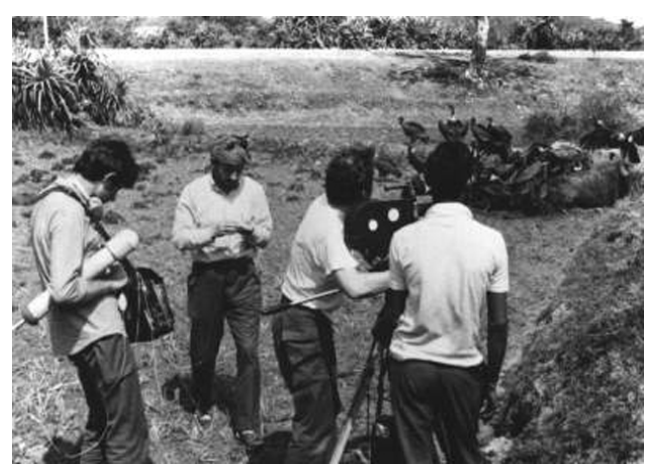




\section{Novas estéticas? Outros diálogos e experiências narrativas}

Mais recentemente, os trabalhos de Dominique Cabrera em Chronique d'une banlieue ordinaire e Jean Arlaud com Ici y'a pas la guerre aportam aspectos criativos à condição de imaginar e fabular na cidade, tratando da memória e da duração.

Neste processo de descoberta do exótico "chez nous", os documentaristas franceses perseguem, neste processo, o lugar do sujeito dando-lhe voz, em entrevistas diretas e relatos contextualizados.

\section{Aqui não estamos em guerra!}

Paris, último dia do ano em

1998, os habitantes do bairro Barbés-

Rochechouart, em Paris, preparam-se para a

festa mundial da passagem do ano.

Administrativamente denominado de bairro

18, este se situa na direção norte da cidade, próximo a principal estação ferroviária conhecida por Estação do Norte.

Jean Arlaud constrói um roteiro que poetiza os distanciamentos sociais e étnicos tanto quanto os transnacionalismos abrindo o documentário com a câmera parada no hotel Select no seio do bairro, como metáfora da passagem do tempo.
Trechos de ficha filmográfica Ici n'a pas de Guerre Ana Luiza C. da Rocha e Cornelia Eckert Paris 7 junho 2001

Neste documentário o diretor Jean Arlaud e a co-diretora Annie Mercier decidem filmar o familiar. Ambos são moradores do bairro. Mas que lugar é este que ambos resolvem escolher como universo de um documentário para falar dos estilos de viver em Paris? Todos conhecem «la Goutte d Or ». Até quase o final do século XIX este território não pertencia ao município de Paris. Territorialidade com impostos mais baratos e próximos da capital era grande atração de migrantes vindos do interior da França e de países vizinhos, sobretudo expulsos do campo e das zonas rurais que se empobreciam em contraste a uma condição de desenvolvimento urbano que atraía todo tipo de mão de obra, toda sorte de tradição cultural. $\mathrm{O}$ fio da história todos conhecem: o fenômeno da industrialização e da urbanização criou um mercado de trabalho sem fronteiras. A partir dos anos 20, associada a questões políticas coloniais, este processo promoveu a imigração de levas africanas de trabalhadores. A alquimia resultou em um bairro pluriétnico, misturando francesas da gema, oriundos da França profunda, os trabalhadores dos países circundantes e uma crescente população africana.

Este é hoje um dos bairros mais densos de Paris, onde predomina a convivência de uma população de origens étnicas diversas concentrando uma população com trajetórias intramares, marcadas por rupturas, despedidas e sentimentos de nostalgia próprios a grupos com suas sagas imigratórias. Todos a sua maneira vivem na cidade parisiense que Arlaud toma como tema de reflexão, com a singularidade de ser o dia mesmo de passagem, de morte e início do novo ano quando povos ocidentais socializam votos, gestos e atenções numa cadeia universal. É por estes tempos e espaços de sociabilidades e interações das diferenças que o diretor narra sua cidade.

Neste roteiro a vida dos moradores do bairro foram sendo costuradas, detalhes cuidados na filmagem, mas também na montagem privilegiando a observação participante e o diálogo neste bairro emblemático, carrefour de comunidades tão diversas, onde alteridades interagem atirando a atenção das antropólogas entusiastas pelo estudo da cidade, e nesta das alteridades, dos jogos de memória e pertencimento, das narrativas de trajetórias e percursos que desenham o urbano com o vivido e o experienciado.

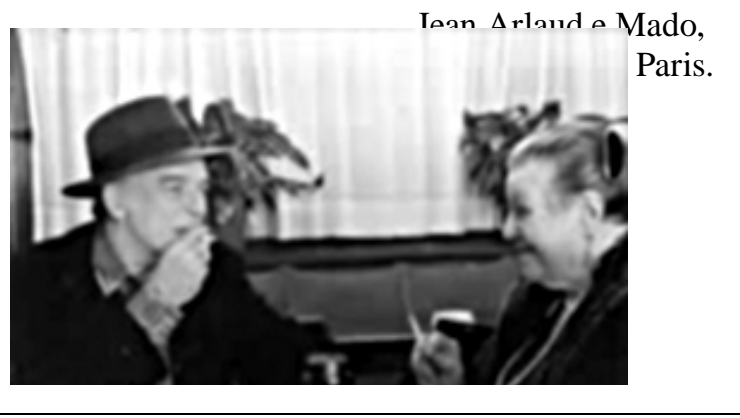




\section{O documentário se inicia pela} visita ao Bar Olympic. Sua patroa atua em ritmo acelerado de final de ano cozinhando para seus clientes. Um a um os personagens vão se revelando na congregação de um cumprimento, de um copo de vinho, uma piada. A chegada do velho morador e freqüentador Marcel é motivo de exclamação da dona do bistrot para a câmera; "meus clientes são um pouco minha família!».

Novamente a câmera se desloca no bairro e o etnógrafo adentra o Bar do Gittan, captando a singularidade étnica simbolizada no preparo de um leitão.

Os cafés-restaurantes visitados se sucedem, desde o típico "pedaço" francês tradicional, passando por universos kabyles, $\quad$ kurdos, yogoslavos, martiniqueses, africanos e chineses, diante do espectador do documentário o cenário da Goutte d'Or se colore de tons, músicas, cheiros e vozes.

As cenas marcadas por uma sucessão de micro eventos em que seus personagens inscrevem os acontecimentos em tradições populares, a festa do ano novo é vivida na sua

Trechos de ficha filmográfica Ici y'a pas la guerre Ana Luiza C. da Rocha e Cornelia Eckert

Paris 7 junho 2001

Filmar a cidade, um cenário que poderia nos conduzir à dispersão por seus estímulos, diria Georg Simmel.

Estamos no quartier Goutte d'Or, em Barbés-Rochechouart, Paris, é véspera da passagem no ano. Alguém partira de volta para o Magreb, alguém escreve uma carta e a lê, voz in off, contextualizando este último dia do ano no bairro em que o sentimento de pertencimento das etnias sem fronteiras se delineia. Aqui temos raízes diz o narrador com uma musica árabe ambientando as lembranças do lugar, do bairro, e das pessoas do cotidiano do bairro que são os personagens do filme.

Ao contrário, em Goutte d'Or, este ato traduz a intimidade dos personagens com os narradores-cineastas, ela adentrando cafés, cabeleireiros e casas de comércio, ela revela o seu conhecimento anterior, sistemático e cuidadoso já que por serem habitués poderiam, pela proximidade, se perder em detalhes significativos apenas para quem tem intimidade com as ruas e os lugares do bairro. Entre a câmera, o narrador e os personagens, há uma discrição e reciprocidade em cada gesto. Aos poucos é a câmera que se torna mais um personagem nas trocas e diálogos já que ela intermedia a cumplicidade de olhares: do antropólogo aos personagens e situações, destes, novamente para o antropólogo, no cruzamento destes olhares vai se construindo o lugar do espectador. Mário faz a barba no pátio de um prédio. Criatividade em face da precariedade das condições. Ele conversa, balbucia palavras brincando com a situação de interagir com a câmera que o observa.
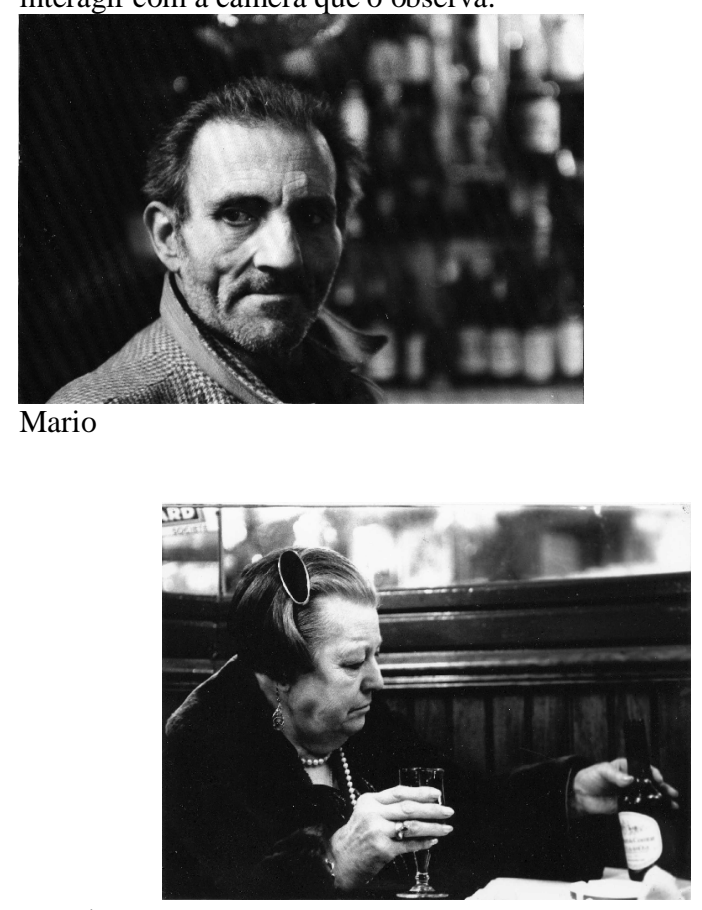

Mado 
dimensão pluriétnica, costumes culturais diversos, vão sendo tecidos numa malha de sentidos tirando do anonimato estes excluídos que não pertencem nem a Rive gauche, nem a Rive droite, pois Barbes, explica o personagem árabe-muçulmano-não-praticante no início do filme, é uma ameaça constante para os bairros do 1 ao 17. Sua heterogeneidade é mal vista e sistematicamente acusada dos males maiores. Mas, como mostra o diretor, o bairro de tantos perigos e medos é igualmente o lugar da reinvenção do cotidiano e das múltiplas formas de viver junto e nem a rejeição os elimina do corpo citadino, onde os sons do metro, os ruídos urbanos, os cheiros de mercados na rua, de temperos árabes, de incensos indianos, de patos a la chinesa, resituam o espectador para além da Paris dos turistas, dos não lugares, dos flanneurs, dos anônimos e dos indiferentes.

$\mathrm{Na}$ rua a câmera se desloca, observando gestos e cenas, captando os percursos dos personagens e seus caminhos de pertença, de vidas cruzadas. Entrecortando os deslocamentos e os encontros, a voz in off aparece e desaparece, entrelaçando as estórias de ontem e as de hoje. Mario encontra o poeta e cantor argelino que anuncia ter feito uma nova música sobre a nostalgia de seu país e familiares na Argélia, e ocupa a cena com sua canção do exílio apreciada por todos. Mas a África é um pouco o bairro, e não nos Le Petit Ici y'a pas la guerre, 1998

surpreende vermos em uma loja especializada em produtos de cinema um comerciante em busca de um projetor $35 \mathrm{~mm}$ para exibição de filmes talvez no interior de algum vilarejo africano. O lá e o aqui, o distante e o perto se aproximam na Goutte Mario e Ziz Ali Ici y'a pas la guerre, 1998 d'Or; a desterritorialização de ontem se

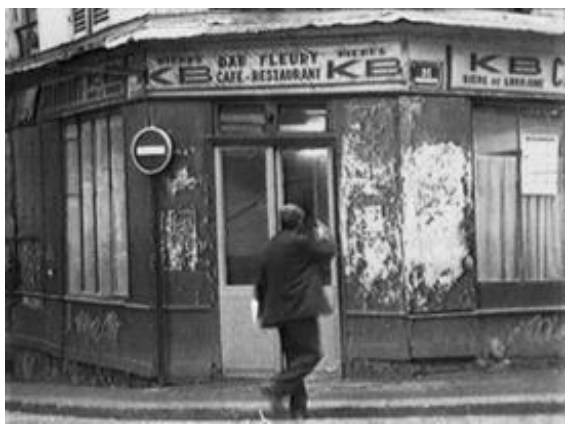


transfigura no enraizamento a uma comunidade pluri-étnica que pertence ao mundo. Lembrando Caetano Veloso, poderíamos dizer que a África é aqui, em Paris!

A estória vai se desenrolando com os preparativos para as festas de Ano Novo no bairro, a passagem do tempo e das rotinas é ritmada por estes personagens que se cruzam e, a esta altura do ano, buscam reorganizar suas lembranças de um exílio que se transforma em êxodo. Mario rouba a cena e explica, entusiasta, o espírito da amizade no mundo e para isto é preciso falar em siciliano e performatizar com gestos das mãos, círculos e corações desenhados no ar. "La conca d'oro, não esqueçam...la conca...d'oro».

\footnotetext{
Trechos de ficha filmográfica Ici y'a pas la guerre Ana Luiza C. da Rocha e Cornelia Eckert Paris 7 junho 2001

O mundo é uma «concha», uma «bacia», um pote de ouro! O quartier Goutte d'Or é isto, «gota de ouro», ela abriga diferentes pessoas, todas elas reunidas, forçosamente, num pequeno canto do mundo palavra. Mario nos da uma aula do significado concreto dos laços de reciprocidade, de dons e contra-dons que Marcel Mauss nos descreveu no «Ensaio da Dádiva ». A câmera continua a percorrer as ruas já desertas e os bistrots lotados. Ela encontra um vendedor de jornal que se desloca, com seu cachorro, de bar em bar e nos seus deslocamentos conduz o espectador aos lugares e aos personagens da estória.
}

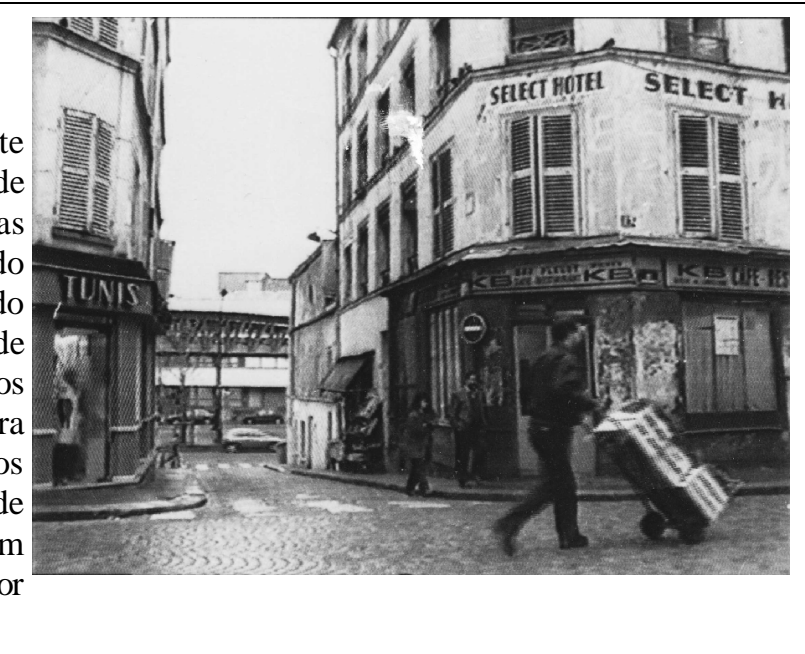

Le Select

Ici y'a pas la guerre, 1998.

A noite se aproxima e moradores vestidos à rigor, com seus trajes de festa, encenam as trocas social : jogos de corpos, de gestos, de olhares, de toques.. Planos fechados nos jogos de seduções, carícias e sorrisos levam o espectador para dentro do espaço cada vez mais apertado da cena social. Feliz ano novo ! O grito rompe o ano que se encerra. Momento em que nosso narrador, lendo a sua carta, descreve o cotidiano de violências nas ruas, durante os movimentos pela libertação da Argélia, em Paris, nos anos 1960. O relato da perseguição, intolerância e da discriminação contrasta com as imagens das trocas sociais íntimas entre os personagens cujas origens diferenciadas se entrelaçam no bairro Goutte d'Or, sob a ameaça de um processo de renovação urbana. 


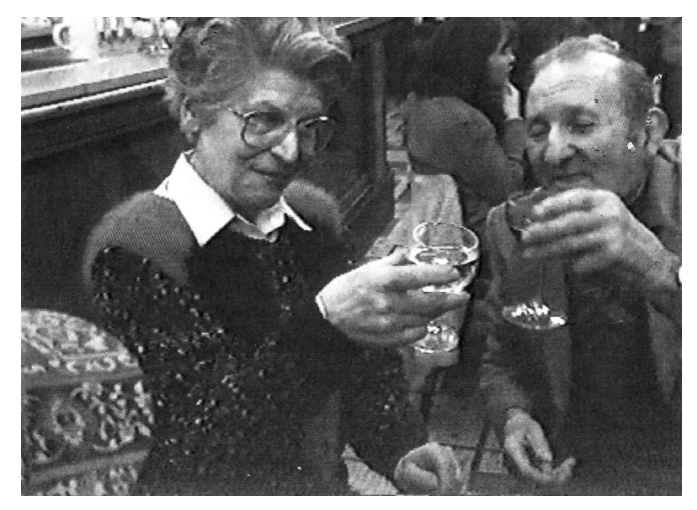

Mme Marcelle

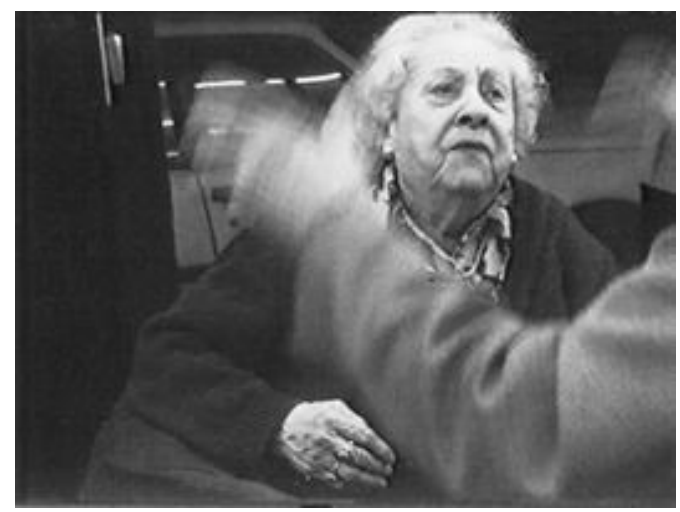

Mme Marinette

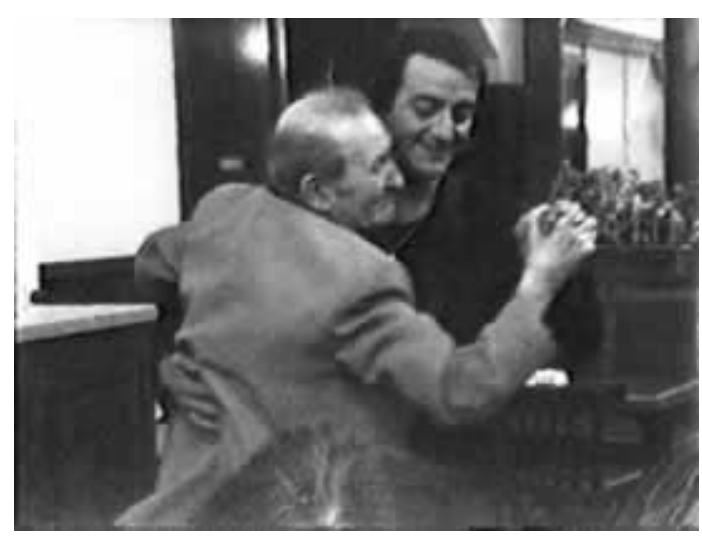

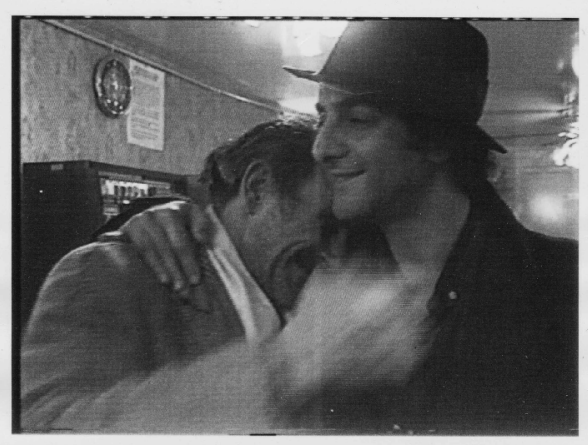
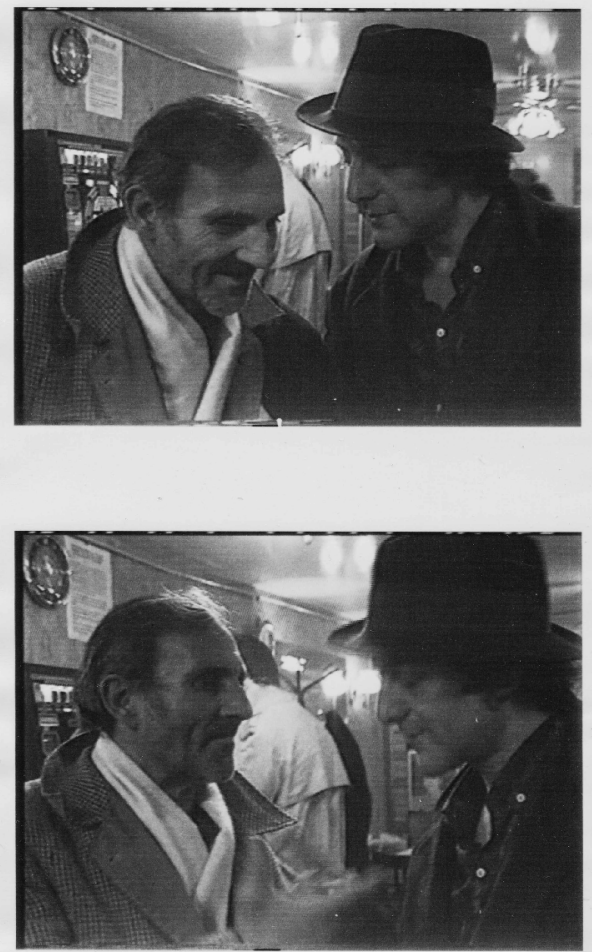

Mario e Ziz Ali

Ici y'a pas la guerre, 1998
Mario e Ziz Ali

Ici y'a pas la guerre, 1998 
Na manhã seguinte, um novo ano se inicia, mas os gestos se repetem, portas se abrem, os fregueses se agitam, Mario bebe seu café e os pequenos rituais de reciprocidade, como emprestar um cigarro ou oferecer um aperitivo, garantem a continuidade do contrato humano de viver. A sua concha de ouro continua lá, acolhedora. Como afirma um dos personagens: "aqui, no bairro, não há guerra!" Mais tarde, Mario assiste a coleção de slides de Michel sobre a chegada do homem à lua e seu espectador se emociona com a excepcionalidade do evento, sendo flagrado pela presença da câmera que testemunha o feliz constrangimento.

A imagem viaja, o imaginário de um pequeno planeta solto no espaço se universaliza e se expande até se chegar na cena final, quando retornamos ao bairro Goutte d'Or, onde alguns homens empurram, rua afora, sob os olhares displicentes dos moradores locais, o enorme equipamento de projeção de filmes $35 \mathrm{~mm}$ que será, finalmente, embarcado, do continente Europeu, diretamente para a África!

Trechos de ficha filmográfica Ici y'a pas la guerre

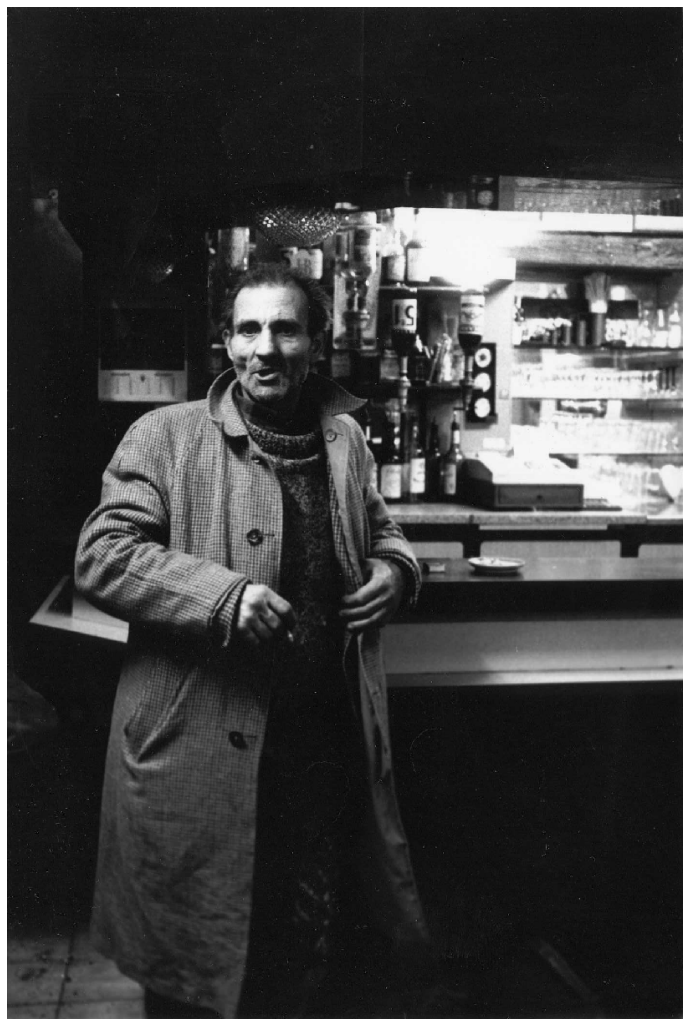
Ana Luiza C. da Rocha e Cornelia Eckert

Paris 7 junho 2001

Seguimos a pensar e produzir sobre como narrar na e a cidade, buscando apontar para novas questões sobre espaços urbanos construídos e vividos, tendo a etnografia áudio-visual como suporte de tradições, de biografias e de reinvenções cotidianas de seus habitantes, onde o registro audiovisual torna-se receptáculo de narrativas que comunica, através de uma linguagem coletiva, uma pluralidade de identidades e memórias.

A proposta aqui não é nos alongarmos com a pesquisa sobre Porto Alegre, mas convidamos o leitor a acessar o site www.estacaoportoalegre.ufrgs.br e após "baixar" o banco de imagens, interagir com nossa forma etnográfica de documentar a cidade, onde temos por fonte de inspiração 
a "sociologia das formas" de Georg Simmel, onde a Cidade é apreendida como revelando em seus territórios a tragédia da cultura: a vida coletiva no teatro da vida urbana das modernas sociedades ocidentais que apresentam-se como ponto de intersecção de vários mundos, vivendo seus atores, seus agentes, seus sujeitos éticos e históricos, enfim, seus personagens, um processo tensional de várias formas de dominação, exploração, coerção de processos sociais abrangentes.

O movimento ordinário da pesquisa é complexo, mas igualmente estimulante no desvendamento das imagens que nos habitam e no reconhecimento do trajeto antropológico e do processo civilizatório que Gilbert Durand (1989) e Norbert Elias (1994) conceberam como gesto de conhecimento e de libertação de determinismos e constrangimentos.

\section{Referências}

Amiel, V. L'esthétique du montage, Paris, Nathan, 1997.

BAKHTIN, M. Questões de literatura e de estética. A teoria do romance. São Paulo, Unesp, Hucitec, 1998.

BARDECHE, M. Histoire du cinéma. Paris, Les Sept Couleurs, 1964.

BARNOUW, E. El documental, historia y estilo, Barcelona, Gedisa, 1993.

BAZIN, A. Qu'est-ce que c'est le cinéma, Paris, Cerf, 2000.

COSTA, R. A outra face do espelho. Jean Rouch e o "outro". 2000. http://bocc.ubi.pt/_esp/autor.php3?codautor=647. Consultas julho e agosto 2003.

DURAND, G. Figures Mythiques et visages de l'œuvre, Paris, Berg International, 1979.

ECKERT, C, ROCHA, A. L. C. "Etnografia de rua e câmera na mão". Revue Electronique Studium, Campinas, Unicamp. 2001/2002 (http://www.studium.iar.unicamp.br/)

ECKERT, C. e ROCHA, A. L. C. "A memória como espaço fantástico". Diverso, Revista de Antropologia Social y Cultural del Uruguay. Montividéu, Uruguais, v.2, 2000. http://www.educar.org/revistas/diverso/

ECKERT, C. e ROCHA, A. L. C. "Filmes de memórias: do ato reflexivo ao gesto criador". In: Cadernos de Antropologia e Imagem UERJ. Rio de Janeiro: 2001

ECKERT, C. e ROCHA, A. L. C. Premissas para o estudo da memória coletiva no mundo urbano contemporâneo sob a ótica dos itinerários de grupos urbanos e suas formas de sociabilidade. In: Revista Margem Tecnologia, Cultura. Faculdade de Ciências Sociais - PUC - SP, EDUCFAPESP. Numero 8. 1998. P. 243 à 259.

ELIAS, N. A sociedade dos indivíduos. Rio de Janeiro, Jorge Zahar Editor, 1994.

DURAND, G. As estruturas antropológicas do imaginário. Lisboa, Presença, 1989.

EWALD, F. «Paul Ricœur: un parcours philosophique », in: Magazine Littéraire, n 390, février 2000.

FERRO, M. Cinéma et Histoire, Paris, Gallimard, 1977.

GAUTHIER, G. Le documentaire: un autre cinéma, Paris, Nathan Cinéma, 1995. 
GERVAISEAU H e VERTOV, D. "Do cinema verdade a arte da passagem entre imagens". CINEMAIS, No 1, out 1996.

LEROI-GOURHAN, A. O Gesto e a Palavra. 2 Memória e Ritmos. Lisboa, Perspectivas, edições 70.

HÉRITIER-AUGÉ, F. “Où et quand commence une culture”, in: Cinémaction?, n 64., 1992.

MACHADO, A. Pré-cinemas \& Pós-Cinemas, São Paulo, Papirus, 1997.

MANOVICH, L. "Computer simmulation and the history of illusion", in: Digital Delirium, A. Kroker et M. Kroker (sous la dir. de), New York, St Martin’s Press, 1977.

MORIN, E et ROUCH, J. Chronique d'un éte in Interspectacles-Domaine cinema, Paris, 1962.

PASSEK, J.-P (sous la dir. de). Dictionnaire du Cinéma, Paris, Larousse, 1995.

PIAULT, M. "Une pensée fertile", in: Cinémaction, n 81, 1994.

PIAULT, M. Anthropologie et Cinéma, Paris, Nathan, 2000.

RANCIERE, J. La fable cinématographique, Paris, Seuil, 2000.

SIMMEL, J. Sociologia. Estudios sobre las formas de socializacion. Buenos Aires, Espasa-Calpe, 1984

\section{Filmografia}

A propos de Nice. Direção Jean Vigo, França, 1929 e 1930.

Babelville. Direção Philippe Baron, França, 1992.

Berlin, symphonie d'une grande ville. Direção Walter Ruttmann. Alemanha, 1927.

Chronique d'un été, Direção : Jean Rouch e Edgar Morin. 1960

Chronique d'une banlieue ordinaire. Direção: Dominique Carrera. Paris, França. 55 minutos. SECAM. Distribuição: Iskra. Produção : Iskra e Canal plus, INA. 1992.

Daguerreotypes. Direção Agnès Varda. Documentario 16 mm. Cores, 1h15m, 1975.

En remontant la rue Villin. Direção de Georges Perec e Robert Bober, Couleur duração 49 minutos.- VF Films, INA, Vidéothèque de Paris, La Sept ARTE Vídeo,.

Etudes sur Paris, Direção de André Sauvage de 1928.

Farrebique. Direção Georges Rouquier, França, 1946.

Ici y’a pas la guerre. Direção : Jean Arlaud. Câmara : Jean Arlaud et Annie Mercier. Local : Rue de la Goutte d'Or, 18 arrondissement, Paris. Especificação : Cor. Duração : 1h15m. Sistema VHS PAL version française. 1998.

L’homme à la caméra, Direção Dziga Vertov, França, 1929.

Le fond de l'air est rouge. Direção de Chris Marker, França, 1997.

Lê joli mai. Direção de Chris Marker, França, 52 minutos,. Prêmio da crítica internacional, Festival de Veneza, Leão de ouro, Festival de Veneza. 1963.

Le silence de Paris, Direção de J.-C. Bringuier, França, 1957.

L'effondrement. Direção de M. Ophuls, França, 1967. 
Les Gens des Baraques. Direção, imagem e som: Robert Bozzi, Produtor: Jacques Dibou, Montage : Brigitte Dornès , Produção: Sept Arte, Périphérie Production, Duração 88 minutos, 1995.

Louisiana Story, Direção de Robert Flaherty, Imagem: Robert Flaherty et Richard Leacock, 75minutos, 1948 .

Nanook of the north, Direção de Robert Flaherty, Canadá, 1922.

Rue des Partants. Direção de Gilles Dinnematin, França, 1995.

Une journée portée disparue. Direção de P. Brooks et A. Hayling, França, 1992. 